\title{
ThinkING About Dispute RESOlution
}

\author{
TREVOR C.W. FARROW*
}

\begin{abstract}
DISPUTE RESOLUTION: READINGS AND CASE STUDIES, Julie Macfarlane et al., eds., $2 d$ ed. (Toronto: Emond Montgomery, 2003)
\end{abstract}

\section{INTRODUCTION}

Non-traditional dispute resolution - "Alternative Dispute Resolution" or "ADR" — in Canada continues to mushroom. ${ }^{2}$ Everyone is getting on board the A-train. Current judges are participating in court-connected processes. ${ }^{3}$ Retired judges are finding new-found careers as mediators and arbitrators. ${ }^{4}$ Lawyers are seeing the potential of the "ADR movement"s as an ever-expanding source of business. ${ }^{6}$ Universities, including law schools and other faculties, are not being left behind. As the editors of Dispute Resolution: Readings and Case Studies have commented, "[s]ince the first edition of this book was published three years ago, the level of interest in dispute resolution - and in particular in the teaching of dispute

- Faculty of Law, University of Alberta.

1 There is significant debate over the meaning of ADR. As Andrew J. Pirie has commented when referring to $A D R$, "there continues to be a complicated fascination with what lies behind these three words." Alternative Dispute Resolution: Skills, Science, and the Law (Toronto: Irwin Law, 2000) at 1 [Skills, Science, and the Law]. Part of this debate stems from the recognition that, given its prevalence, ADR is no longer "alternative." Many theorists and practitioners now refer to ADR, in its current form, simply as "Dispute Resolution" or "DR." See $e . g$. the casebook at issue in this review: Julie Macfarlane et al., eds., Dispute Resolution: Readings and Case Studies, 2d ed. (Toronto: Emond Montgomery, 2003) [Readings and Case Studies]. See also Stephen B. Goldberg et al., eds., Dispute Resolution: Negotiation, Mediation, and Other Processes, 4th ed. (New York: Aspen Law \& Business, 2003) [Negotiation, Mediation, and Other Processes]; John S. Murray, Alan Scott Rau \& Edward F. Sherman, Processes of Dispute Resolution: The Role of Lawyers, 3d ed. (Westbury, NY: The Foundation Press, 2002) [Role of Lawyers]. For the purpose of this review, however, I will use the term $\mathrm{ADR}$ as it has come to be commonly used in legal scholarship and practice.

2 As one commentator has noted, "[a]lternative dispute resolution has become a dynamic area of legal practice. Individuals and institutions are increasingly using arbitration, mediation, and other alternative mechanisms to resolve disputes that grow out of private transactions." Katherine V.W. Stone, Private Justice: The Law of Alternative Dispute Resolution (New York: Foundation Press, 2000) at iii [Private Justice].

3. In Alberta, judges of both the Court of Queen's Bench and the Provincial Court regularly participate in Judicial Dispute Resolution processes. See e.g. Dave Hancock, "The Alberta Civil Courts in the 21 st Century," 25 Newsletter (Canadian Bar Association, August 2000), online: Canadian Bar Association $<w w w . c b a-a l b e r t a . o r g / P u b l i c a t i o n s / N e w s l e t t e r A u g 2000 . p d f>$; Government of Alberta, News Release, "Judicial Dispute Resolution Program a Success" (22 May 2002), online: Government of Alberta <www.gov.ab.ca/acn/200205/12396.html>.

4 The ADR Chambers in Toronto, for example, advertises itself as "Canada's largest group of retired Judges, Senior Counsel and other ADR experts." See ADR Chambers advertisement (January/February 2003) 12 National 29.

$5 \quad$ Skills, Science, and the Law, supra note lat 1.

- As one recent Ontario advertisement stated: "In many cases, mediation is mandatory. Choosing DRS [Dispute Resolution Services] isn't." Dispute Resolution Services advertisement, (2003), 63 O.R. (3d) Part 7 at xli (Professional Announcements). 
resolution - has risen exponentially." And together with this increased interest, there has been an ever-expanding body of ADR literature ${ }^{8}$ and online materials. ${ }^{9}$

In my view, by building on a very useful first edition, ${ }^{10}$ the editors of this casebook have produced an excellent source for students, instructors, and practitioners, thereby providing a meaningful contribution to this exciting area of scholarship. I say this for four reasons: (1) the casebook includes a broad range of useful topics and materials; (2) it does a good job of including Canadian content; (3) its pedagogical focus is largely successful; and (4) it is relatively user-friendly.

\section{TOPICS AND MATERIALS}

The casebook tries to do a great deal for a great number of audiences. As the editors themselves acknowledge, its "principle goal" is "to provide a book for university and college students who are studying dispute resolution ... at the undergraduate and graduate levels, both in law school and in other departments and disciplines ... from a range of disciplinary backgrounds."

Readings and Case Studies, supra note 1 at xvii.

While this review does not purport to canvass exhaustively this literature, for general discussions and source materials, see e.g. Catherine E. Bell \& Trevor C.W. Farrow, Dispute Resolution: Selected Materials (2002) [Casebook, archived at John A. Weir Memorial Law Library, University of Alberta]; Mark D. Bennett \& Michelle S.G. Hermann, The Art of Mediation (Notre Dame: National Institute for Trial Advocacy, 1996); Laurence Boulle \& Kathleen J. Kelly, Mediation: Principles, Process, Practice, Cdn. ed. (Toronto: Butterworths, 1998); J. William Breslin \& Jeffrey Z. Rubin, eds., Negotiation Theory \& Practice (Cambridge, Mass.: Program on Negotiation at Harvard Law School, 1993); Henry J. Brown \& Arthur L. Marriott, ADR Principles and Practice, 2d ed. (London: Sweet \& Maxwell, 1999); Edward Brunet \& Charles B. Craver, Alternative Dispute Resolution: The Advocate's Perspective, 2d ed. (Newark: Lexis Nexis, 2001); Genevieve A. Chornenki \& Christine E. Hart, Bypass Court: A Dispute Resolution Handbook, 2d ed. (Toronto: Butterworths, 2001); David J. Corry, Negotiation: The Art of Mutual Gains Bargaining (Aurora: Canada Law Book, 2000); Roger Fisher \& Scott Brown, Getting Together: Building Relationships As We Negotiate (New York: Penguin Books, 1989); Roger Fisher, William Ury \& Bruce Patton, Getting to Yes: Negotiating Agreement Without Giving In, 2d ed. (New York: Penguin Books, 1991); Roger Fisher, Elizabeth Kopelman \& Andrea Kupfer Schneider, Beyond Machiavelli: Tools for Coping with Conflict (New York: Penguin Books, 1996); Negotiation, Mediation, and Other Processes, supra note 1; Julie Macfarlane, ed., Rethinking Disputes: The Mediation Alternative (Toronto: Emond Montgomery, 1997); Readings and Case Studies, supra note 1, Carrie Menkel-Meadow, ed., Mediation: Theory, Policy and Practice (Burlington, VT: Ashgate Publishing, 2001); Role of Lawyers, supra note 1; Michael Palmer \& Simon Roberts, Dispute Processes: ADR and the Primary Forms of Decision Making (London: Butterworths, 1998); Skills, Science, and the Law, supra note 1; Private Justice, supra note 2; Marcus Stone, Representing Clients in Mediation: A New Professional Skill (London: Butterworths, 1998).

See e.g. online: Canadian Foundation for Dispute Resolution <www.cfdr.org >; "Alternative Dispute Resolution (ADR): An Overview," Legal Information Institute, online: Cornell Law School, <www.law. cornell.edu/topics/adr.html>; online: International ADR <www.international adr.com>; "Arbitration \& Dispute Resolution," Bora Laskin Law Library, online: University of Toronto, <www.law-lib. utoronto.ca/resources/topic/arbit.htm>; University of Victoria, Institute for Dispute Resolution, online: Institute for Dispute Resolution <www.dispute.resolution.uvic.ca/>.

Julie Macfarlane, ed., Dispute Resolution: Readings and Case Studies (Toronto: Emond Montgomery Publications Limited, 1999).

1 Readings and Case Studies, supra note 1 at xvii-xix. 
By not limiting itself to the law school context, the casebook's topics not only focus on the legal aspects of ADR, but on disputes themselves, as both legal and social phenomena. Before getting into materials on a number of the typical ADR processes, ${ }^{12}$ in Chapter One, the editors look at the topic of "conflict analysis" generally. ${ }^{13}$ This set of materials includes sources on the "roots" and "course" of conflicts, how a "problem turn[s] into a dispute," "conflict management," and "conflict and culture." While this chapter only scratches the surface of broader social conflict scholarship, ${ }^{14}$ it is helpful - particularly for law students - as background material to facilitate understanding of how legal conflicts can be situated in broader thinking about social conflict.

Following the introductory chapter, the casebook includes - in what I consider to be its core chapters - materials on negotiation, ${ }^{15}$ mediation, ${ }^{16}$ and arbitration. ${ }^{17}$ I consider these the core chapters because, for the specific purpose of teaching, their topics form the "meat and potatoes" of the ADR movement. ${ }^{18}$ As a result, they also form the core of many current law school ADR courses. ${ }^{19}$

In terms of the materials included in these three chapters, they do a good job of covering the basic aspects of ADR tools. They also go beyond simple description and look at some of the more interesting, important, and critical aspects of these processes. For example, in John

12 These typically include negotiation, mediation, arbitration, and other, more recent, hybrid processes. See e.g. ibid. at xviii. For useful discussions and descriptions of these different ADR processes, see e.g. Negotiation, Mediation, and Other Processes, supra note 1 at 3; D. Paul Emond, "Alternative Dispute Resolution: A Conceptual Overview" in D. Paul Emond, ed., Commercial Dispute Resolution: Alternatives to Litigation (Aurora: Canada Law Book, 1989) at 1-25 ["A Conceptual Overview"]; Skills, Science, and the Law, supra note 1 at 85-90. See also Alison E. Gerencser, "Alternative Dispute Resolution Has Morphed into Mediation: Standards of Conduct Must Be Changed" (1998) 50 Fla. L. Rev. 843.

13 Readings and Case Studies, supra note 1 at 1-108.

14 See Robert A. Baruch Bush \& Joseph P. Folger, "Changing People, Not Just Situations: A Transformative View of Conflict and Mediation" in The Promise of Mediation: Responding to Conflict Through Empowerment and Recognition (San Francisco: Jossey-Bass, 1994); Clyde H. Coombs \& George S. Avrunin, The Structure of Conflict (Hillsdale, N.J.: Lawrence Erlbaum Associates, 1988), Herbert C. Kelman \& V. Lee Hamilton, Crimes of Obedience: Toward a Social Psychology of Authority and Responsibility (New Haven: Yale University Press, 1989); Ronald J. Fisher, Interactive Conflict Resolution (Syracuse: Syracuse University Press, 1997); Michael S. Lund, Preventing Violent Conflicts: A Strategy for Preventive Diplomacy (Washington: United States Institute of Peace Press, 1996); Bernard S. Mayer, The Dynamics of Conflict Resolution: A Practitioner's Guide (San Francisco: Jossey-Bass, 2000); Dean G. Pruitt \& Peter J. Carnevale, Negotiation in Social Conflict (Buckingham: Open University Press, 1993); Dean G. Pruitt, Jeffrey Z. Rubin \& Sung Hee Kim, Social Conflict: Escalation, Stalemate, and Settlement, 2d ed. (New York: McGraw-Hill, 1994); Thomas L. Saaty \& Joyce M. Alexander, Conflict Resolution: The Analytic Hierarchy Approach (New York: Praeger, 1989). See also Lon L. Fuller, "Mediation - Its Forms and Functions" (1971) 44 S. Cal. L. Rev. 305, reprinted in Kenneth I. Winston, ed., The Principles of Social Order: Selected Essays of Lon L. Fuller, rev. ed. (Oxford: Hart Publishing, 2001) at 141-173; Thomas C. Schelling, The Strategy of Conflict (Cambridge, MA: Harvard University Press, 1960, reprinted 1997) at 119-61.

Readings and Case Studies, supra note 1 at c. 2.

Ibid. at c. 3.

Ibid. at c. 6.

18 As Pirie has indicated, the "primary" processes are "adjudication" [including arbitration], mediation, and negotiation" (Skills, Science, and the Law, supra note 1 at 81).

19 . See e.g. Trevor C.W. Farrow, "Alternative Dispute Resolution" (course outline), online: University of Alberta, Faculty of Law <www.law.ualberta.ca/courses/farrow/adr/index.htm $>$. 
Manwaring's chapter on negotiation, ${ }^{20}$ he includes materials dealing with issues of race, gender, culture, and power. ${ }^{21}$ While the reader is left wanting to some extent with these materials, given the breadth of the project, the included materials provide an adequate base for discussion and further research. Also, the lack of material on gender and culture, for example, is more reflective of the general need for further scholarship in these areas than a failing on the part of the editors.

Also raised in several places in these core chapters is the issue of ADR and ethics. Given the expanding role for lawyers and judges in the development of the ADR movement, questions as to the scope and adequacy of traditional codes of ethics are increasingly being raised and discussed..$^{22}$ The editors have looked at this issue in both the context of negotiation and mediation. ${ }^{23}$ Again, while brief given the scope of the work, the editors have adequately introduced and discussed this important issue.

In addition to negotiation, mediation and arbitration, "hybrid" processes - including neutral evaluation, court-annexed processes, the mini-trial, and others - have become essential aspects of the modern ADR movement. For example, court-annexed processes, including mandatory mediation ${ }^{24}$ and judicial dispute resolution, ${ }^{25}$ are becoming equal in importance to traditional litigation processes for the modern litigator. Ellen Zweibel looks at a number of these hybrid processes. The materials, including those on court-annexed initiatives ${ }^{26}$ are quite useful. Having said that, I think they would have been even more useful, particularly to law students, if they had included further materials on the exciting developments that are going on in the various Canadian jurisdictions that are experimenting with these court-annexed processes. ${ }^{27}$ But again, you cannot please everyone all of the time.

Ellen Zweibel has also put together a new chapter in this edition dealing with the novel and exciting topic of "online dispute resolution" (ODR). Basically, ODR contemplates

Readings and Case Studies, supra note 1 at c. 2.

Ibid. at 180-215.

Carrie Menkel-Meadow has, in particular, done a significant amount of work on the issue of ADR and ethics. See "Ethics Issues in Arbitration and Related Dispute Resolution Processes: What's Happening and What's Not" (2002) 56 U. Miami L. Rev. 949; "Ethics in ADR: The Many 'Cs' of Professional Responsibility and Dispute Resolution" (2001)28 Fordham Urb. L.J. 979; "Ethics and Professionalism in Non-Adversarial Lawyering" (1999) 27 Fla. State Univ. L. Rev. 153; "Ethics in Alternative Dispute Resolution: New Issues, No Answers from the Adversary Conception of Lawyers' Responsibilities" (1997) 38 So. Tex. L. Rev. 407. See also Alvin B. Rubin, "A Causerie on Lawyers' Ethics in Negotiation" (1975) 35 La. L. Rev. 577.

Readings and Case Studies, supra note 1 at 258-80, 482-511.

As noted by a recent Canadian Bar Association report, mandatory mediation processes, that "require litigants to try their cases before trial" are part of the civil process in British Columbia, Saskatchewan, and Ontario (Janice Mucalov, "Mediation, Like it or Not" (January/February 2003) 12 National 26 at 26 ["Mediation, Like it or Not"]).

Alberta, for example, has made significant use of this judge-run, court-annexed, mediation-style process. See supra note 3 and accompanying text.

Readings and Case Studies, supra note 1, c. 5 at 410-19. Further, as discussed infra, notes 31-40 and accompanying text, I am strongly supportive of the project's general efforts to include Canadian content.

For recent summary discussions of these developments, see e.g. "Mediation, Like it or Not," supra note 24; Canadian Forum on Civil Justice, "Cross Country Snapshot of Dispute Resolution" (Spring 2002) 4 News \& Views on Civil Justice Reform 12. 
"traditional" ADR processes being modified and experimented with in online, computerbased media. They are providing even faster, cheaper, and more accessible alternatives to their fast, cheap, and accessible ADR forerunners. ${ }^{28}$ Whether or not ODR processes will become standard tools of the litigator remains to be seen. However, including this chapter does two positive things for the casebook. First, it includes materials on a leading-edge development in the ADR world. Second, and more importantly, it demonstrates to students the expansive and changing nature of this topic. Flexibility, experimentation, and novelty have been important aspects of the ADR movement and its success. Including these materials on ODR drives home the importance and reality of these aspects.

Finally, the editors have included a chapter on "designing and evaluating dispute resolution systems." 29 Again, we see the scope of the project at work. In my view, this chapter is as relevant to social studies and systems design as it is to the study of law. For law students, it represents a potentially important tool in the discussion and understanding of which processes will work in what contexts. ${ }^{30} \mathrm{Being}$ able to evaluate a process takes students a long way down the road, as future lawyers, toward being able to recommend appropriate processes for a given context. This skill will apply equally to proactive advice, in the form of dispute resolution clauses in contracts, as to retrospective dispute resolution advice given by litigators.

\section{Canadian Content}

Law and legal scholarship have clearly not escaped the clutches of globalization. For a long time now, Canadian jurists - judges, lawyers, and academics - have been relying on American and other foreign authorities as persuasive material for the development of our own scholarship and legal thinking. ADR is no different. And given its flexibility and non-rulebased nature, in many ways it is less jurisdiction-specific than most other areas of legal thinking and practice.

Having said that, the roots of the modern ADR movement stem largely from the United States. ${ }^{31}$ As a result, much of the available material used to study these processes has traditionally been American. ${ }^{32}$ Readings and Case Studies draws heavily on American materials. This is not a criticism, as Canadian dispute resolution scholars continue to rely on the expansive American ADR scholarship. Therefore, these American materials are largely well-chosen and well-placed. However, while drawing on a significant base of American thinking, the editors have also sought to provide us with broad exposure to the "critical mass of Canadian scholarship" that has developed in the past number of years. ${ }^{33}$ This, in my view, is the book's most valuable contribution, particularly in the context of teaching ADR in Canada.

See Janet Rifkin, "Online Dispute Resolution: Theory and Practice of the Fourth Party" (2001) 19 Conflict Res. Q. 117, reprinted in Readings and Case Studies, supra note 1 at 521.

Ibid. at c. 7.

For a seminal work on this question, see Frank E.A. Sander \& Stephen B. Goldberg, "Fitting the Forum to the Fuss: A User-Friendly Guide to Selecting an ADR Procedure" (1994) 10 Neg. J. 49.

Readings and Case Studies, supra note 1 at xvii.

Ibid.

Ibid. 
The cross-jurisdictional nature of ADR can be both a blessing and a curse. On the one hand, its flexibility and "jurisdictionless" nature allows for jurists of many different jurisdictions to practice and talk together in the same language, largely unencumbered by local rules and procedures. For example, when I was practicing as a litigator in Toronto, I acted for a Colorado-based corporation against a Texas-based corporation in a commercial arbitration held in Phoenix, Arizona. This proceeding was governed substantively by Michigan law and procedurally by the U.S. Federal Rules of Civil Procedure ${ }^{34}$ and the American Arbitration Association (AAA) Commercial Arbitration Rules.$^{35}$ Given that the contract at issue in the dispute had a binding dispute resolution clause ensuring resolution by private arbitration under the rules of the AAA, Canadian and American lawyers could act in the same process without belonging to a specific local bar. Given the increased movement of lawyers both within and between countries, these sorts of dispute resolution scenarios are likely to become more commonplace.

However, culture still plays an important role in the understanding of, and participation in, local disputes and dispute resolution processes. As Pirie has acknowledged when discussing "conflict and conflict resolution across cultures," culture - through "behaviour" — is "relevant to understanding conflict and conflict resolution.... [T] he presence or absence of certain behaviours can be important to the course conflict takes." nature of ADR, unless it is adapted to fit a given culture, has the potential to homogenize otherwise distinct disputes and process requirements. Therefore, as is discussed in some of the articles included in the casebook, ${ }^{37}$ taking culture seriously is an important aspect of the modern ADR movement. ${ }^{38}$

Taking culture seriously is equally important when approaching our scholarship. To the extent that Canadian legal culture differs from that of the United States, encouraging Canadian-focused scholarship will allow one to take seriously that difference. Further, to the extent that we as Canadians seek to protect that difference, encouraging and highlighting Canadian research projects and scholarship will help with this effort. I therefore applaud the efforts of the editors to recognize the "relevance of Canadian perspectives to the enhancement of the field" ${ }^{\prime 39}$ through the recent and important contributions of Canadian scholars to the ADR movement. ${ }^{40}$

28 U.S.C. (2002), online: United States House of Representatives <www.house.gov/judiciary/ Civil2002.pdfs.

American Arbitration Association, online: American Arbitration Association <www.adr.org/index2.1.

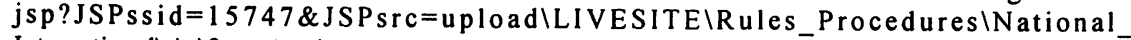

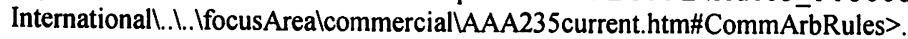

Skills, Science, and the Law, supra note 1 at 293-94.

See Readings and Case Studies, supra note 1 at 204-209, 732-38.

See also generally Skills, Science, and the Law, supra note 1 at 282-306.

Readings and Case Studies, supra note 1 at xvii-xviii.

Useful examples of this scholarship include, for example, Julie Macfarlane, "Why Do People Settle?" (2001) 46 McGill L.J. 663; "ADR: A Conceptual Overview," supra note 12, excerpted in Readings and Case Studies, supra note 1 at 71-74, 104-106. I am also grateful to the editors for including references to a recent interdisciplinary work of mine: Trevor C.W. Farrow, "Negotiation, Mediation, Globalization Protests and Police: Right Processes; Wrong System, Issues, Parties and Time" (2003) 28 Queen's L.J. 665, discussed in Readings and Case Studies, ibid. at 221 and 266. 


\section{Pedagogical focus}

Regardless of where one comes out on the age-old debate about whether law school is about learning the law or about learning how to think about the law, ${ }^{41}$ there is no doubt that the study of ADR lends itself well to the problem-based approach. The editors of Readings and Case Studies obviously agree. As they state in the preface to the second edition, the "central pedagogical principle" of the book - expanding upon their approach to the first edition - is that "dispute resolution theory takes its meaning from dispute resolution practice." ${ }^{42}$

In addition to the chosen materials, this principle manifests itself largely through the "notes and questions" sections that are included throughout the casebook. In these sections, together with certain longer case studies, ${ }^{43}$ students are provided with small thought experiments, hypothetical exercises, and questions designed to push their thinking through theory application. While not exclusively problem-driven, ${ }^{44}$ the casebook includes a number of useful examples and hypothetical exercises.

These exercises will not replace more comprehensive case studies and exercises. ${ }^{45}$ In my experience, students often find detailed role-play exercises involving multiple parties and complex fact scenarios to be of significant value when learning how to apply theory to practice. However, the exercises included by the editors do provide instructors and students with short, useful tools - in context - that help to bring alive the theories and principles that are discussed in the various readings.

\section{USER-FRIENDLY}

Like its first edition predecessor, the case book is well-organized, well-edited, and generally user-friendly. Its organization lends itself to a topic-based ADR course or set of course offerings. To the extent that instructors wish not to supplement it with additional readings and case studies, ${ }^{46}$ the casebook could stand on its own in terms of an adequate source of materials for an interactive theory/practice-based ADR course.

On a final, procedural note, the inclusion of an index ${ }^{47}$ has made this second edition an improvement over the first. As a general matter, the utility of texts and casebooks that do not include indices is, in my view, greatly reduced. The first edition of this casebook suffered

As S.M. Waddams has commented, "[t]here has always been and there will always be a tension in legal education between the practical and the academic." Introduction to the Study of Law, 5th ed. (Scarborough: Carswell, 1997) at 17.

Readings and Case Studies, supra note 1 at xviii.

See e.g. ibid. at 111-15.

For an excellent example of a fully problem-driven casebook, see Andrew L. Kaufman \& David B. Wilkins, Problems in Professional Responsibility for a Changing Profession, 4th ed. (Durham, NC: Carolina Academic Press, 2002).

Some of the more well-known case studies are those that have been developed at the Program on Negotiation at Harvard Law School. See e.g. Bruce M. Patton, "Eazy's Garage" (Cambridge, MA: Program on Negotiation, Harvard Law School, 1997).

See, however, my comments on the need for additional case exercises, ibid. and accompanying text. Readings and Case Studies, supra note 1 at 833-37. 
from that problem. However, notwithstanding this improvement, the index is relatively brief and at times incomplete. For example, if you are looking for materials dealing with the issue of ADR and ethics, you would be better off looking at the casebook's table of contents than its index. In the index, when looking alphabetically for "ethics," you will find an entry for "ethical frameworks, negotiation" 48 that directs you to one section in the negotiation chapter. ${ }^{49}$ In the table of contents, however, you will find several references to additional materials dealing with ethics, specifically in the context of mediation, which do not appear conveniently in the index..$^{50}$ Expanding the index would, in my view, make for an even more useful third edition of the casebook. However, in the end, while this is an important point, it does not ultimately detract from the overall positive accomplishments of the casebook as a whole. ${ }^{51}$

\section{Conclusion}

ADR instructors have a wide variety of texts and casebooks from which to choose when assigning and recommending course materials. There are several quality casebooks in the marketplace. ${ }^{52}$ Given the largely American focus of American law school curricula, I do not see Readings and Case Studies becoming a leading source outside of Canada. However, based on my review and use of the casebook, I recommend it highly to Canadian as well as to foreign students, instructors, and practitioners. I see it as a strong and welcome addition to the scholarship in this area.

Ibid. at 835.

Ibid. at 258-66.

See $i$ bid. at xi, referring to materials in ibid. at 493-500.

Further, to the extent that the complete text of the casebook, in PDF format, is available on CD, this indexing and searching criticism becomes moot. While examination copies of the casebook exist on $C D$, it does not appear that the $\mathrm{CD}$ format of the casebook is commercially available. For a web-description of the casebook, see Emond Montgomery Publications, online: Emond Montgomery Publications $<$ www.emp.on.ca/books/130-2.html>. 